\title{
El emprendedor y las etapas para crear su empresa
}

El individuo capaz de crear valor, riqueza y empleo, pasa de ser emprendedor a empresario/creador de empresas. Para cumplir esa meta es necesario captar recursos externos que permitan a esta nueva empresa desarrollarse en el mercado, así como generar valor al cliente para conseguir su satisfacción y fidelización, incorporando la filosofía del marketing en su plan de empresa, fusionando la pasión y la gestión en el proceso empresarial.

En el año 1987, Rumelt, describió al emprendedor con las siguientes características: creatividad, capacidad de comunicación, negociación, toma de decisiones, arriesgado, resistente al fracaso, orientado a buscar oportunidades, éstas, las debe desarrollar con todo su potencial y energía, pero a su vez, debe también potenciar su capacidad de gestión empresarial.

La unión entre la dirección estratégica y el emprendimiento, se lo denomina emprendimiento estratégico, que consiste en el conjunto de deberes, procesos, decisiones, acciones formuladas $y$ ejecutadas por el emprendedor, quién a su vez, debe contar con recursos, diseño organizativo y estrategias. (Hitt, Ireland, Camp y Sexton, 2001).

Esencialmente el emprendimiento identifica las necesidades de los potenciales clientes, lo que permite, determinar oportunidades y proponer soluciones innovadoras que cubran los requerimientos del mercado.

La creación de empresas es el resultado de una secuencia lógica que se deriva del individuo/emprendedor y el proyecto empresarial que desea desarrollar.

También, es preciso conocer si su idea/oportunidad es viable y para descubrirlo debe elaborar un plan de empresa debidamente estructurado, que indique cuántos recursos necesita (financieros, humanos, tecnológicos), cómo y en qué tiempo los tiene que utilizar, con esa información conocerá los términos de su inversión inicial, cuyo financiamiento puede ser con dinero propio o externo y, en el caso de este último deberá buscar ayuda externa, como: familiares, instituciones financieras, organizaciones $\sin$ fines de lucro, etc.

Finalmente, la empresa debe constituirse de manera formal y legal para iniciar sus operaciones.
Figura 1: Etapas para la creación de empresas

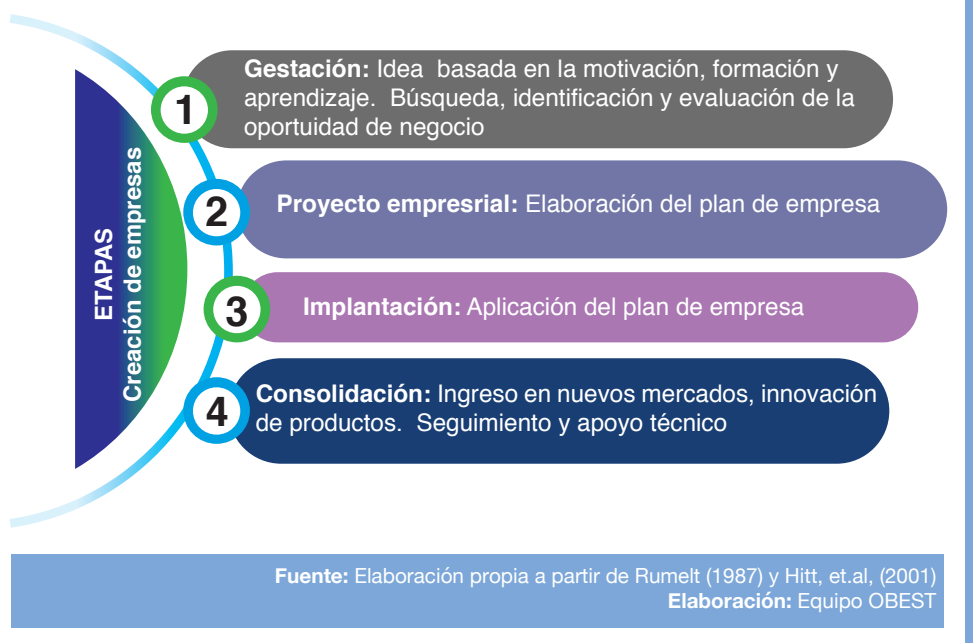

Referencias:

- Hitt M.A.; Ireland R.D.; Camp S.M.; Sexton D.L. (2001): “Guest Editor's Introduction to the special issue strategic entrepreneurship: Entrepreneurial strategies for wealth creation". Strategic Mangement Journal, vol 22 págs 479-491.

- Rumelt, R.P. (1987). "Theory, strategy and entrepreneurship". En: DJ. Teece. The competititve challenge: Strategies for industrial innovation and renewal, Ballinger. Cambridge, MA, págs.137-158.

Elaboración:

Lcda Lorena Rivera Badillo M.Sc. 